\title{
PRODUCTION OF HIGH-PURITY CADMIUM SINGLE CRYSTALS BY VERTICAL DIRECTED CRYSTALLIZATION METHOD
}

\author{
(D)Alexey P. Shcherban ${ }^{\mathrm{a}, *}$, (D)Gennadiy P. Kovtun ${ }^{\mathrm{a}, \mathrm{b}}$, (D)Ditriy A. Solopikhin ${ }^{\mathrm{a}}$, \\ (D)Yuri V. Gorbenko ${ }^{a}$, (DIgor V. Kolodiy ${ }^{a}$, Vladimir D. Virich ${ }^{\mathbf{a}}$ \\ ${ }^{a}$ National Science Center "Kharkiv Institute of Physics and Technology" \\ 1, Academichna str., 61108 Kharkiv, Ukraine \\ ${ }^{b}$ V.N. Karazin Kharkiv National University, 4 Svobody Sq., 61022 Kharkiv, Ukraine \\ *Corresponding Author: shcherban@kipt.kharkov.ua \\ Received March 30, 2020; revised May 8; accepted May 12, 2020
}

\begin{abstract}
The process of producing high-purity Cd crystals by the vertical directed crystallization (VDC) from a melt according to the Bridgman method is investigated. Single crystals with the preferred growth direction [11.2] and [10.3] were produced. The angles of deviation of the growth direction relative to the axis of the samples are $\alpha=27.2^{\circ}$ and $\alpha=0.5^{\circ}$. The crystal perfection, microstructure and microhardness of the grown crystals are determined. As shown by x-ray diffraction analysis, in this VDC variant of high-purity cadmium, a perfect single-crystal structure is not reached. In the start section there are separate grains with different orientations, the amount of which decreases in the end section of the single crystal. This results in the formation of a more perfect single-crystal structure with a preferred orientation, which occupies the entire cross section of the crystal. The microhardness of the upper and lower sections of single crystals was determined. The more contaminated end sections of the crystals have lower microhardness than the initial parts. The impurity composition of the start and end sections of single crystals produced from cadmium of various grades purity was studied. The efficiency of impurity elements redistribution along single crystals is the same for different grades of cadmium. The developed VDC process can be used for growing single crystals of low-melting metals, such as $\mathrm{Zn}, \mathrm{Pb}, \mathrm{Te}$, In, Bi, Sn, etc.
\end{abstract}

KEY WORDS: cadmium, vertical directed crystallization, single crystals, growth direction, microstructure, microhardness, impurity composition

Recently, the need for single crystals of metals for practical and research purposes has been increasing. For this reason, a new industry has increased - single crystal growing. Single crystals of metals and semiconductors are produced by growing from a melt mainly in three ways: vertical directed crystallization (VDC) - the Bridgman method [1]; pulling from a melt onto a seed - the Czochralski method [2, 3] and crucibleless melting - the Pfann method [4].

The history of the development of technique for single crystals growing by the VDC method totals about 100 years. The first papers on the growth of VDC crystals were those of Tamman (1923) [5]. In 1924, L.V. Obreimov and L.V. Shubnikov implemented the VDC method in which single crystals were grown in a vertical fixed tubular container cooled by compressed air [6]. P. Bridgman in 1925 made constructive changes to the proposed VDC method. In this method the container became movable. D. Stockbarger in 1937 introduced additional design changes to the Bridgman VDC process. A two-section heater with a diaphragm in its middle was proposed here to provide a larger temperature gradient at the crystallization front. In 1925, Bridgman prepared single crystals of $\mathrm{Sn}, \mathrm{Cd}, \mathrm{Zn}, \mathrm{Sb}, \mathrm{Bi}$, and Te by the VDC method. Since then, researchers have been working both on improving technological methods for growing single crystals, and on achieving a perfect structure and quality of the producing single crystals.

The advantage of the VDC method is that it allows one to grow large sizes single crystals of square, rectangular or round cross sections. The cross section of a single crystal is determined by the shape of the container. A significant drawback of this method is that the crystallization front is not visible during solidification process. This drawback can be partially overcome by installing thermocouples in a container for measuring temperatures and thus determining the position of the crystallization front and the temperature gradient at the crystallization front.

Goals of article is to study the process of producing high-purity bulk cadmium single crystals by the VDC method without use of seed.

\section{MATERIALS AND METHODS}

Two grades of metal were used as the initial material for producing high-purity cadmium single crystals by the VDC method: cadmium of initial purity $>99.99 \%$, which corresponds to the technical grade Cd0A, and cadmium of high-purity $>99.999 \%$, which corresponds to a cadmium grade of Cd00 high-purity. High-purity cadmium was produced by the complex method of distillation in vacuum [7, 8]. The directions of growth orientation were determined for the produced $\mathrm{Cd}$ single crystals, their structural perfection was studied, changes in the microhardness and impurity composition of the start and end parts of single crystals were determined.

Diffractometric studies of the samples were carried out on a DRON-2.0 X-ray diffractometer with cobalt Co-K $\alpha$ radiation applying a Fe selectively absorbing filter. Diffracted radiation was detected by a scintillation detector. 
Analysis of crystallographic orientation (CGO) and crystal perfection was carried out from the butt-end of the rods by the rotating crystal method. Samples for X-ray and microstructural studies were cut by electrospark cutting perpendicular to the axis of the rods (see Fig. 1). The surfaces of samples were prepared by grinding and polishing according to a standard technique followed by etching in a reagent of the following composition: chromic anhydride $10 \mathrm{~g}$; hydrochloric acid $-1 \mathrm{ml}$; water $-100 \mathrm{ml}$.

Microhardness was measured according to the Vickers method on a PMT-3 instrument with a load of $10 \mathrm{~g}$. The microstructure was studied using an MMP-4 light microscope.

The impurity composition of single crystals was determined by laser mass spectrometry using the EMAL-2 type mass spectrometer.

\section{EXPERIMENTAL SECTION}

The process of growing single crystals by the Bridgman VDC method is carried out in special facilities in vacuum, inert atmosphere, hydrogen and in air. The Bridgman method is suitable for metals with a relatively low melting point and small chemical activity. These limitations arise due to the difficulty in selecting the material of the cruciblecontainer. Typically, crucibles made of graphite, quartz, aluminum oxide are used.

The study of the process of producing cadmium single crystals was carried out in a facility, the heat unit and mounting of which were modernized for the process of single crystals growth by the vertical Bridgman method. A special device was manufactured, the scheme of which is given in paper [9]. A container with molten cadmium was pulled down from the heater to a cold region, where, as it was pulled, a single-crystal structure of arbitrary orientation was formed.

To carry out the processes of cadmium directed crystallization, a special container was made of high-purity dense graphite of MPG-7 grade. The impurity composition of such graphite is given in paper [10]. The container had a conical shape at the bottom with an apex angle of $40^{\circ}$. Before use, the container was annealed at $\sim 1000{ }^{\circ} \mathrm{C}$ in a vacuum of $1 \ldots 3 \mathrm{~Pa}$ for half an hour. The crystals were grown with a crystallization rate of 0.37 to $0.24 \mathrm{~mm} / \mathrm{min}$ under a pressure in the facility chamber within 1.7...1.9 atm of pure argon. The temperature gradient at the crystallization front ranged from 14.4 to $15.0^{\circ} \mathrm{C} / \mathrm{cm}$.

\section{RESULTS AND DISCUSSION}

Figure 1 shows the external view of A and B cadmium single crystals produced by the described above method of vertical directed crystallization.

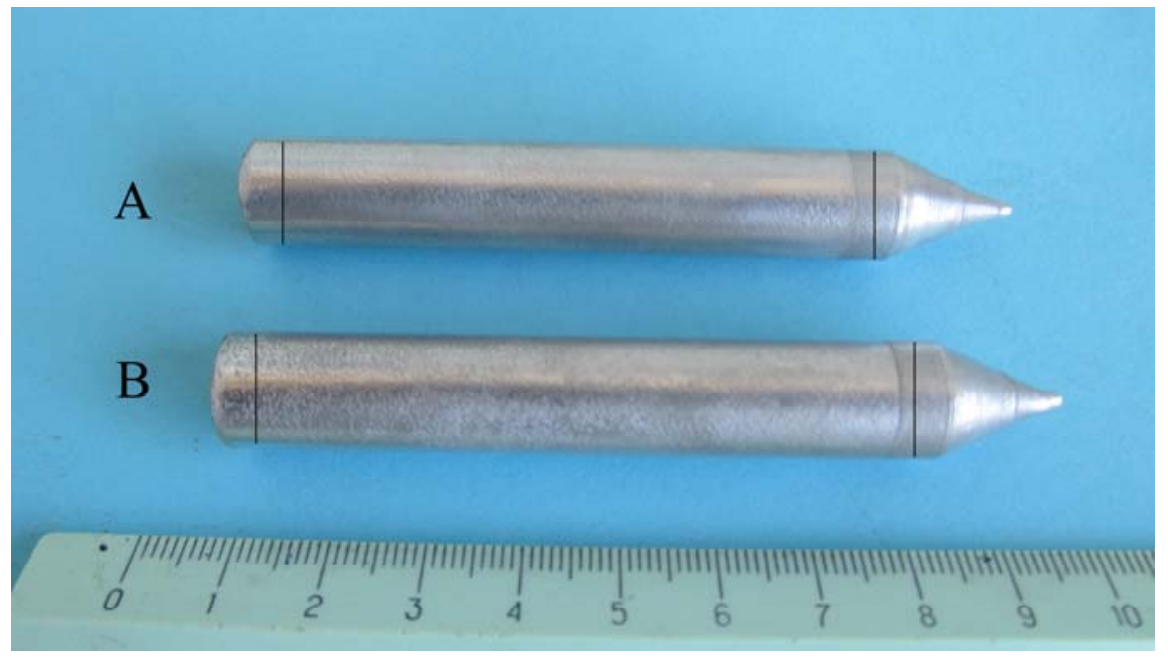

Figure 1. External view of single crystals of cadmium A and B with marked places of cutting samples for research

Figure 2 shows the diffraction patterns of the start a) and end b) sections of the single crystal A, recorded according to the $\langle\theta-2 \theta »$ scanning scheme. It can be seen that low-intensity diffraction lines are present on the diffraction patterns. The lines (11.2) are with the maximum intensity, that is, the crystallographic planes (11.2) are oriented parallel to the plane of the end face of the crystal. The presence of other lines in the diffractogram indicates the presence of grains in the sample with a different orientation.

An analysis of the crystallographic orientation (CGO) and the degree of perfection of the single crystal (Figure 3) showed that the deviation of the crystallographic direction from the normal to the butt-end part is $\alpha=27^{\circ}$. Also, from the start side a) the presence of a block with a misorientation angle $\Delta \alpha=0.5^{\circ}$ from the main maximum was revealed. In addition to the main maximum, additional maximums were also revealed at the angles of $3.3^{\circ}$ and $0.6^{\circ}$ with the start side a) (indicated by the arrow) and $3.0^{\circ}$ with the end side, which also indicates the presence of grains with a different orientation. 


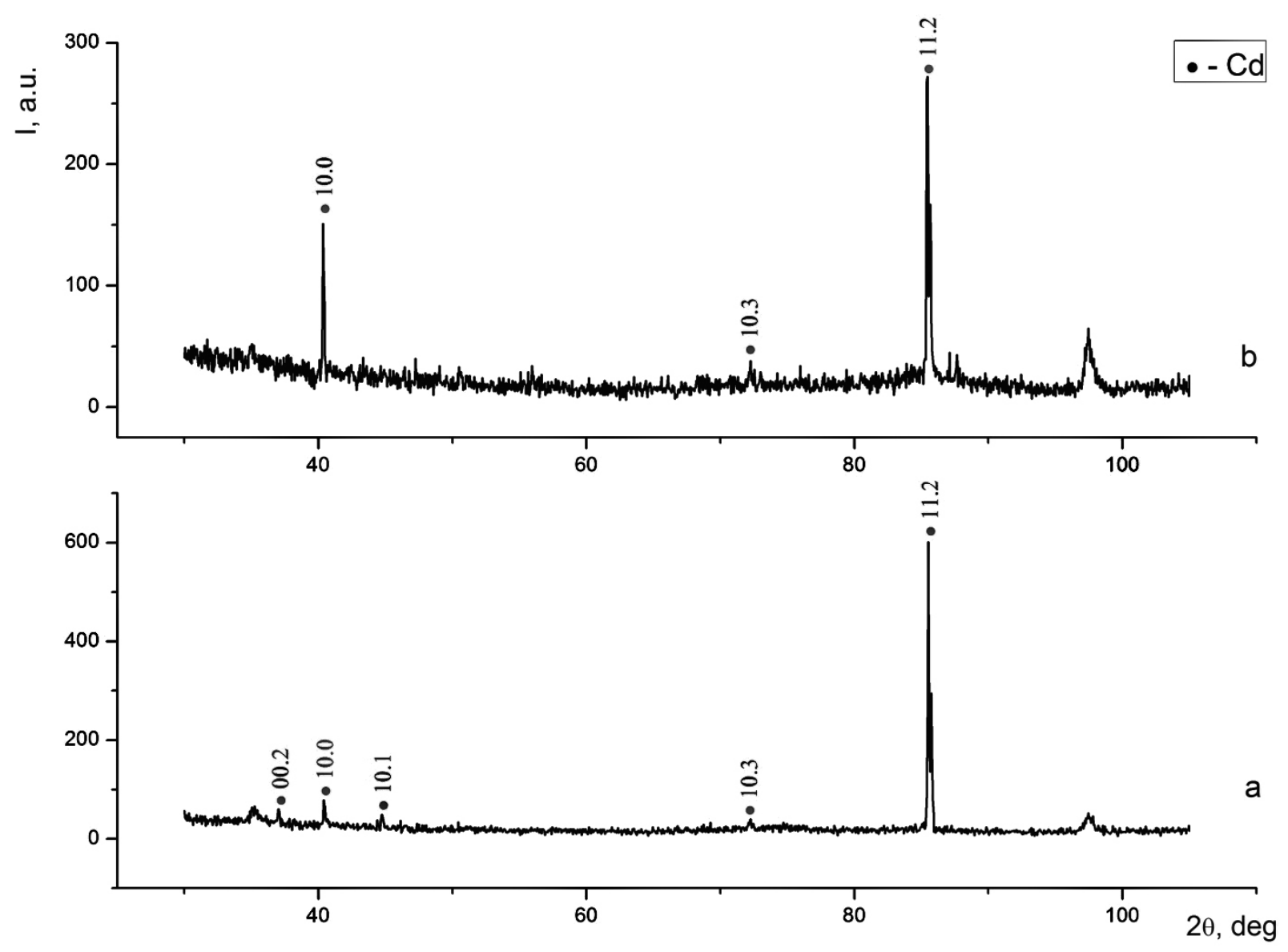

Figure 2. Diffraction patterns of the start a) and end b) sections of single crystal A

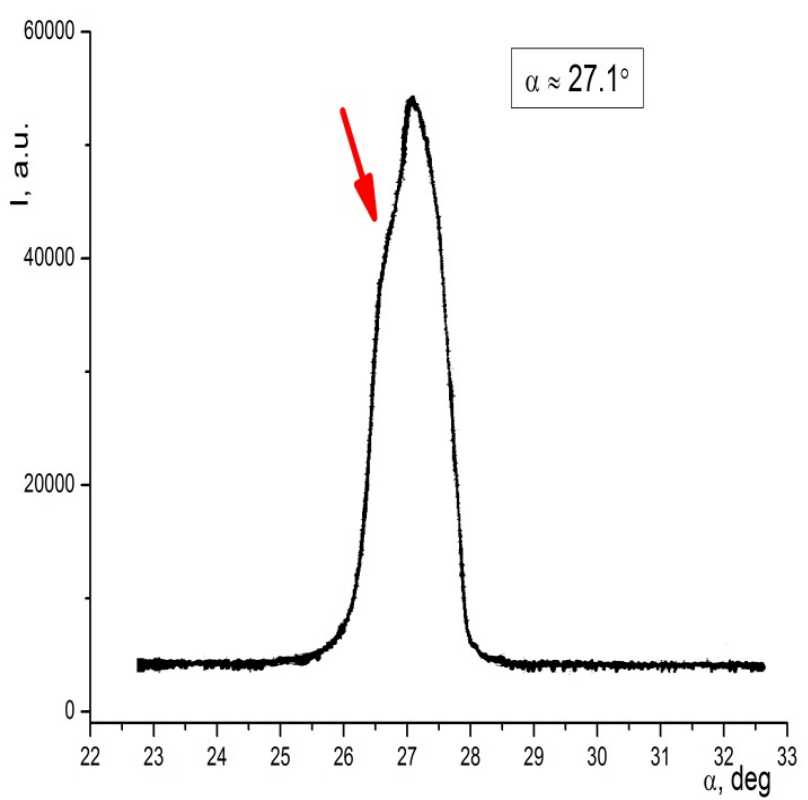

a)

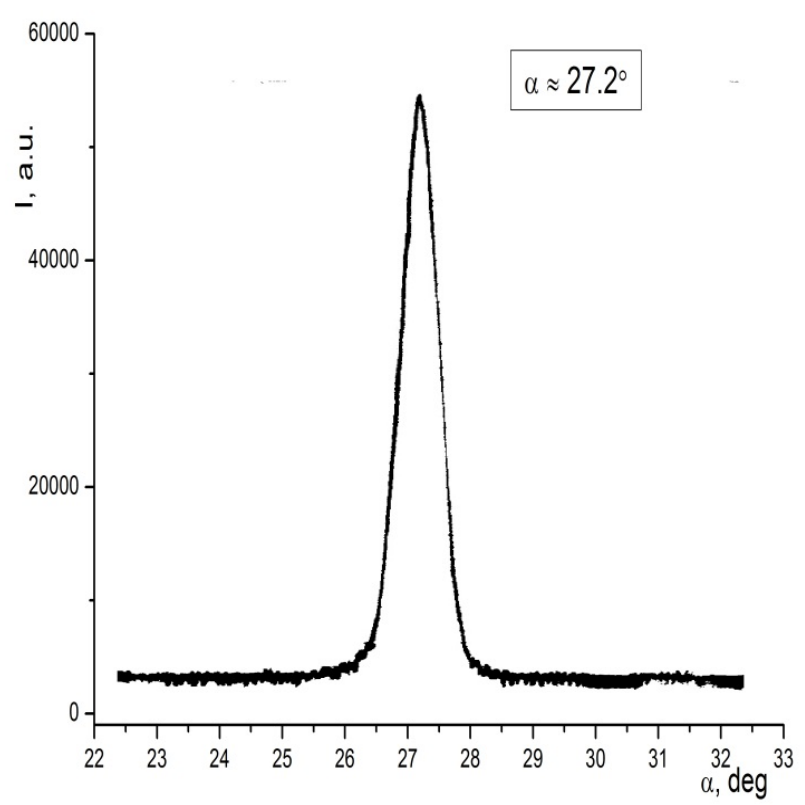

b)

Figure 3. The plot of the diffraction pattern of sample A (determination of orientation)

Figure 2, 3 shows that the main direction of orientation of the lower and upper parts of the single crystal is retained, and hence it is hold over the entire length of the sample.

Similarly X-ray diffraction analysis was performed for single crystal B. The diffraction patterns of the starting a) and end b) part of the single crystal $B$ are shown on Figure 4.

It can be seen that the lines (10.3) have the maximum intensity, i.e., the crystallographic planes (10.3) are oriented parallel to the plane of the crystal butt-end. 


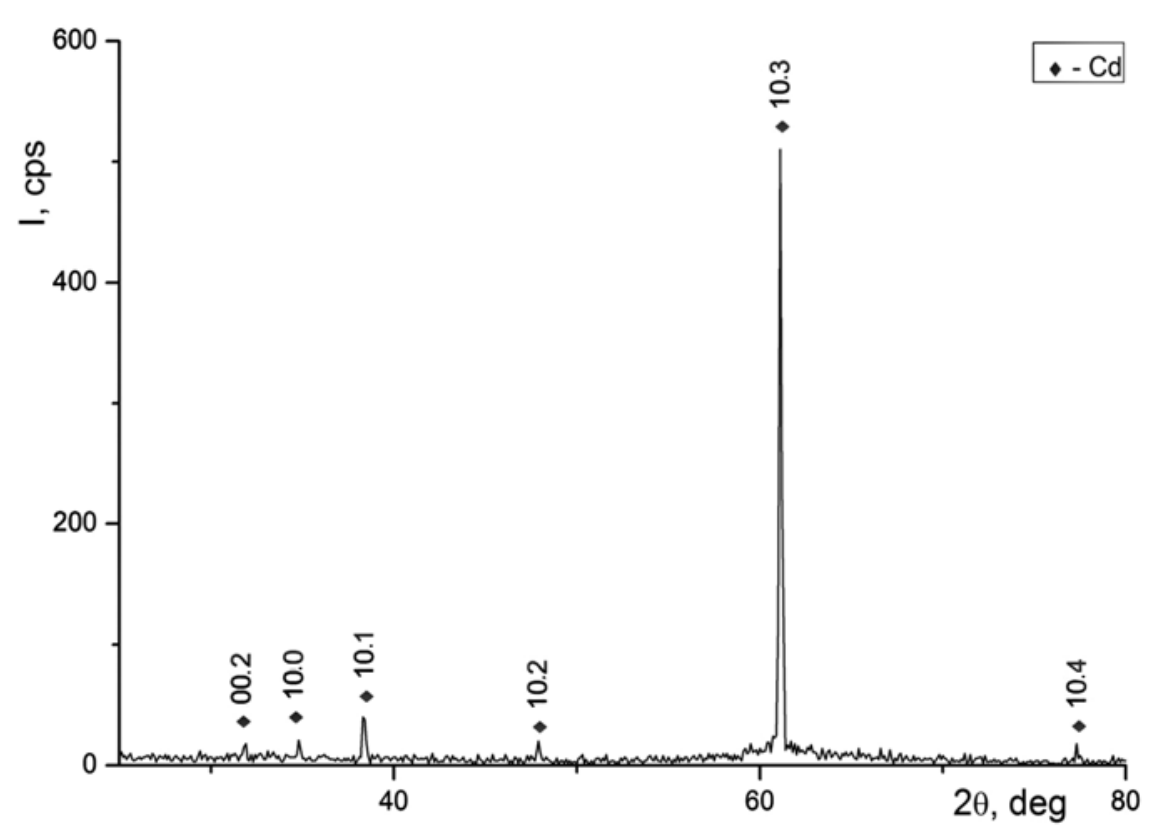

a)

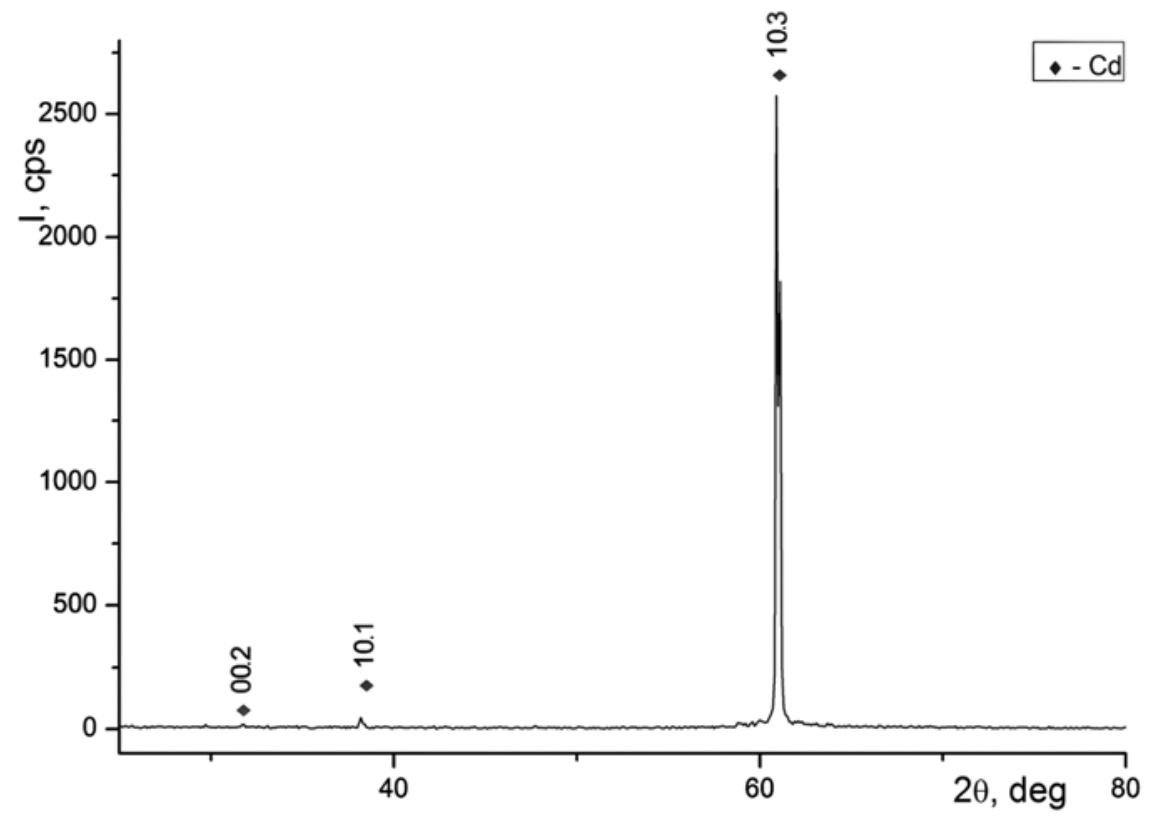

b)

Figure 4. Diffraction patterns of the starting a) and end b) part of the single crystal B

The presence of other low-intensity lines in the diffractogram indicates the presence of grains with a different orientation. The determination of CGO and the analysis of the degree of perfection of single crystal B were performed by the upper part of the single crystal. Diffractometric studies showed that the deviation of the crystallographic direction from the normal to the end part is $\alpha=0.5^{\circ}$. The presence of a block with a misorientation angle of $0.8^{\circ}$ relative to the main maximum was revealed. Thus, the studied crystals A and B are the single crystals with an imperfect structure. The development of grains with a different orientation in the initial stage of growth is a characteristic feature in seedless directed crystallization of low-melting metals [11].

During growth process, due to the preferential orientation of the crystal, the fine grains disappear, which leads to the formation of a more perfect single-crystal structure which occupies the entire cross section of the crystal. In the above variant of VDC of the high purity cadmium, as X-ray diffraction analysis shows, the complete disappearance of small grains does not occur nevertheless. The reason for this may be possibly a low gradient at the crystallization front. Metallography does not reveal the presence of grains in the upper section of the grown crystals (Figure 5).

Table 1 shows the microhardness of the starting and end section of cadmium single crystals A and B. The measurements were performed at the indenter load of $10 \mathrm{~g}$. The Table 1 shows that the microhardness of cadmium crystals in the end section decreases compared with the starting section for both crystals, which does not correlate with 
the overall purity of these parts. Reference data on microhardness values are $H_{\mu}=29 \pm 1 \mathrm{~kg} / \mathrm{mm}^{2}$ [12]. Microhardness measurements were performed on polycrystalline cadmium of the $99.8 \%$ purity at a load of $10 \mathrm{~g}$, as in our case.

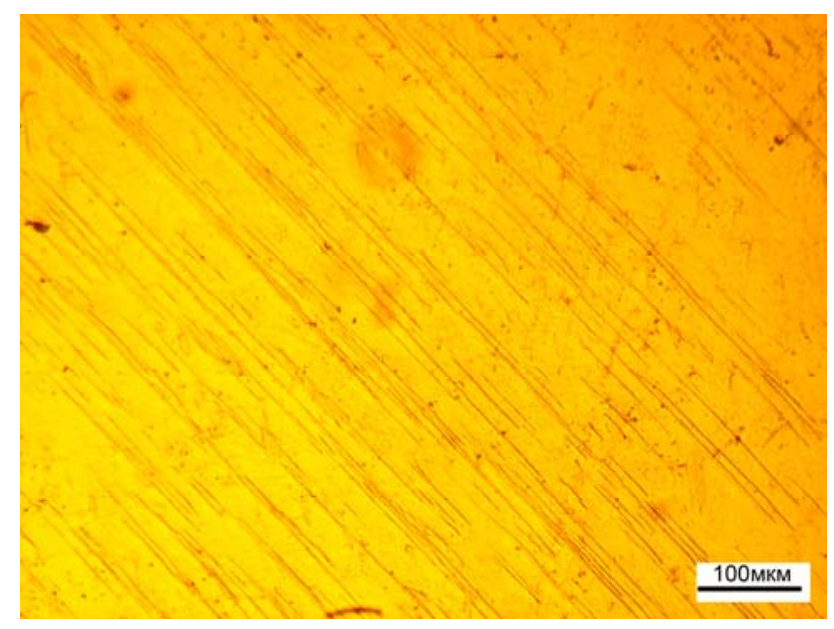

Figure 5. The microstructure of a high-purity cadmium single crystal B

Table 1

The microhardness of cadmium crystals $\mathrm{H}_{\mu}, \mathrm{kg} / \mathrm{mm}^{2}$ and their degree of purity, \%

\begin{tabular}{|c|c|c|c|}
\hline \multicolumn{2}{|c|}{ Crystal A } & \multicolumn{2}{c|}{ Crystal B } \\
\hline start section & end section & start section & end section \\
\hline $24 \pm 1$ & $21 \pm 2$ & $21 \pm 3$ & $18,5 \pm 2$ \\
\hline$>99.995$ & $>99.98$ & $>99.999$ & $>99.998$ \\
\hline
\end{tabular}

Table 2 shows the impurity composition of the start and end sections of cadmium single crystals A and B produced from a metal of various initial purities.

Table 2

The impurity composition of cadmium single crystals, $\times 10^{-4} \mathrm{wt} . \%$

\begin{tabular}{|c|c|c|c|c|}
\hline \multirow{2}{*}{ Element } & \multicolumn{2}{|c|}{ Crystal A } & \multicolumn{2}{c|}{ Crystal B } \\
\cline { 2 - 5 } & start section & end section & start section & end section \\
\hline $\mathrm{Na}$ & 0.08 & 0.1 & 0.05 & 0.2 \\
$\mathrm{Mg}$ & 0.2 & 0.05 & 0.1 & 0.04 \\
$\mathrm{Al}$ & $<0.01$ & 0.05 & 0.02 & 0.05 \\
$\mathrm{Si}$ & $<0.1$ & $<0.1$ & $<0.1$ & $<0.1$ \\
$\mathrm{~S}$ & 0.1 & 0.5 & 0.2 & 0.4 \\
$\mathrm{Cl}$ & 0.03 & 0.4 & 0.08 & 0.2 \\
$\mathrm{~K}$ & 0.05 & 0.04 & 0.1 & 0.1 \\
$\mathrm{Ca}$ & 0.4 & 0.5 & 0.2 & 0.4 \\
$\mathrm{Fe}$ & $<0.1$ & 80 & $<0.1$ & $<0.1$ \\
$\mathrm{Cu}$ & 30 & 3 & 3 & 2 \\
$\mathrm{Zn}$ & 1 & 6 & 0.7 & $<0.2$ \\
$\mathrm{Ag}$ & 7 & 4 & $<0.2$ & $<0.3$ \\
$\mathrm{Te}$ & 4 & 80 & $<0.3$ & 7.5 \\
$\mathrm{~Pb}$ & 5 & $>99.98$ & $>99.999$ & $>99.998$ \\
$\mathrm{Cd} \%$ & $>99.995$ & & \\
\hline
\end{tabular}

The content of the remaining 58 impurities from $\mathrm{Li}$ to $\mathrm{U}$ is below the detection limit of laser mass spectrometry $-<(0.7 \ldots 0.07) \cdot 10^{-4}$ wt. $\%$.

The Table 2 shows that there is a slight redistribution of impurities along the crystals in accordance with the equilibrium distribution coefficients of impurities in cadmium. Most of the analyzed impurity elements in cadmium have equilibrium distribution coefficients $\mathrm{k}_{0}<1$ and they displace to the end of the ingot. The exception is $\mathrm{Mg}$ and $\mathrm{Ag}$ impurities for which $\kappa_{0}>1: \kappa_{0 \mathrm{Mg}}=1.9$ и к $\mathrm{K}_{0 \mathrm{Ag}}=2.73$ [13]. Therefore, redistribution of impurities to the start and end part of single crystals should occur, depending on the sign of $\mathrm{k}_{0}$, which is confirmed by the data in Table 2 . The cleanest part of the crystals will be the middle those. The degree of distribution of impurity elements along the length of the crystals, with the exception of $\mathrm{Pb}$, is insignificant. 
In continuation of this work, it is proposed to develop and manufacture a device for growing more perfect and oriented single crystals of cadmium and other low-melting metals.

\section{CONCLUSIONS}

1. The process of production of high-purity Cd single crystals by the VDC method from a melt without using monocrystalline seeds was investigated. As the crystal grows, an increase the perfection of the single-crystal structure is observed.

2. By the X-ray diffraction method the orientations of the studied Cd single crystals were determined, the growth direction of which is [11.2] and [10.3] The angles of deviation of the growth direction relative to the axis of the samples are $\alpha=27.2^{\circ}$ and $\alpha=0.5^{\circ}$.

3. The microstructure and microhardness of the start and end parts of the grown crystals were determined. The microhardness of the end part is lower compared to the microhardness of the start cleaner part of the crystal.

4. The content of impurities in the start and end parts of the grown cadmium single crystals of various degrees of purity was determined. It was revealed that the redistribution of impurity elements at VDC is insignificant along the length of the grown cadmium single crystals.

\section{ORCID IDs}

Alexey P. Shcherban, https://orcid.org/0000-0002-6004-0579; Gennadiy P. Kovtun, https://orcid.org/0000-0003-4242-7697; Dmitriy A. Solopikhin, https://orcid.org/0000-0003-1426-8713; (1)Yuri V. Gorbenko, https://orcid.org/0000-0002-0652-8629; IIgor V. Kolodiy, https://orcid.org/0000-0001-8598-9732

\section{REFERENCES}

[1] R.A. Laudise, and R.L. Parker, Рост монокристаллов [The Growth of Single Crystals], (Mir, Moscow, 1974), pp. 540. (in Russian)

[2] D.T.J. Hurle, Journal of Crystal Growth, 85(1-2), 1-8 (1987); https://doi.org/10.1016/0022-0248(87)90197-7.

[3] G. Muller, Crystal Research and Technology, 42 (12), 1150-1161 (2007); https://doi.org/10.1002/crat.200711001.

[4] W.G. Pfann, Зонная плавка [Zone Melting], (Mir, Moscow, 1970), pp. 366. (in Russian)

[5] G. Carpenter, Металлический кристалл [Metal Crystal], Physics-Uspekhi, 10 (5-6), 689-718 (1930); https://doi.org/10.3367/UFNr.0010.193005d.0689. (in Russian)

[6] O.G. Kozlova, Рост кристаллов [Crystal Growth], Edited by N.V. Belov. (Moscow State University Publishing House, Moscow, 1967), pp. 238. (In Russian)

[7] G.P. Kovtun, D.A. Solopikhin, and A.P. Shcherban, Глубокое рафинирование легкоплавких металлов дистилляцией в вакууме [Deep Refining of Fusible Metals by the Vacuum Distillation], (Scientific World, Moscow, 2018), pp. 494-513. (In Russian)

[8] A.P. Shcherban, Получение высокочистых металлов для производства низкофоновых сиинтилляиионных детекторов редких событий [Obtaining High Purity Metals for Low Background Scintillating Detectors of Rare Events], Problems of Atomic Science and Technology, Series" Vacuum, Pure Materials, Superconductors”, 6(76), 3-10 (2011). (in Russian)

[9] A.P. Shcherban, G.P. Kovtun, D.A. Solopikhin, Yu.V. Gorbenko, T.Yu. Rudycheva, D.G. Malykhin, I.V. Kolodiy, and V.D. Virych, Problems of Atomic Science and Technology, Series "Vacuum, Pure Materials, Superconductors", 1(125), 17-20 (2020).

[10] V.K. Komar, and V.M. Pusikov, $A^{I I} B^{V I}$ монокристалль. Poсm, свойства, применение $\left[A^{I I} B^{V I}\right.$ Single Crystals. Growth, Properties, Application], (Institute of Single Crystals, Kharkiv, 2002), pp. 244 p. (in Russian)

[11] W.C. Winegard, An Introduction to the Solidification of Metals, (London, 1964), pp. 150.

[12] A.A. Ivanko, Твердость. Справочник [Hardness. Reference Book], (Naukova Dumka”, Kiev, 1968), pp. 127. (in Russian)

[13] G.P. Kovtun, A.P. Shcherban, and O.A Datsenko, Классификачия поведения примесей в цинке, кадмии и теллуре при кристаллизационной очистке [The Classification Behaviour of Impurities in Zinc, Cadmium and Tellurium under Purification by Crystallization], Problems of Atomic Science and Technology, Series "Vacuum, Pure Materials, Superconductors", 6, 16-20 (2004). (in Russian)

\section{ОТРИМАННЯ ВИСОКОЧИСТИХ МОНОКРИСТАЛІВ КАДМІЮ МЕТОДОМ ВЕРТИКАЛЬНОЇ СПРЯМОВАНОЇ КРИСТАЛІЗАЦЇ̈}

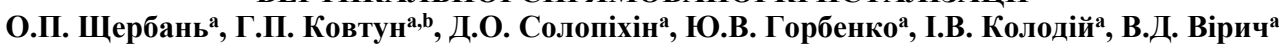

${ }^{a}$ Національний науковий центр Харківський фізико-технічний інститут вул. Академічна, 1, 61108, Харків, Україна

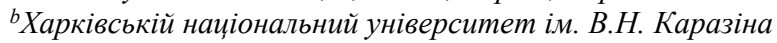
майдан Свободи, 4, 61022, Харків, Украӥна

Досліджений процес отримання високочистих спрямованих кристалів Сd вертикальною спрямованою кристалізацією (ВСК) по методу Бриджмена з розплаву. Отримано монокристали з переважним напрямком росту [11.2] i [10.3]. Кути відхилення напрямку росту відносно осі зразків складають $\alpha=27,2^{\circ}$ i $\alpha=0,5^{\circ}$. Визначено кристалічну досконалість, мікроструктуру $\mathrm{i}$ мікротвердість вирощених монокристалів. Як показує рентгеноструктурний аналіз, в даному варіанті ВСК високочистого кадмію, досконала монокристалічна структура не досягається. У початковій частині присутні окремі зерна 3 різною орієнтацією, кількість яких зменшується в кінцевій частині монокристала. Це призводить до формування більш досконалої монокристалічної структури 3 переважною орієнтацією, яка займає весь переріз кристала. Визначена мікротвердість верхньої і нижньої частин монокристалів. Більш забруднені кінцеві частини кристалів мають більш низьку мікротвердість, ніж початкові частини. Досліджено домішковий склад початкової і кінцевої частин монокристалів, отриманих 3 кадмію 
різної чистоти. Ефективність перерозподілу домішкових елементів вздовж монокристалів однакова для різних марок кадмію. Розроблений процес ВСК може бути використаний для вирощування монокристалів легкоплавких металів, таких як $\mathrm{Zn}, \mathrm{Pb}, \mathrm{Te}, \mathrm{In}, \mathrm{Bi}, \mathrm{Sn}$ та ін.

КЛЮЧОВІ СЛОВА: кадмій, вертикальна спрямована кристалізація, монокристали, напрямок росту, мікроструктура, мікротвердість, домішковий склад

\section{ПОЛУЧЕНИЕ ВЫСОКОЧИСТЫХ МОНОКРИСТАЛЛОВ КАДМИЯ МЕТОДОМ ВЕРТИКАЛЬНОЙ НАПРАВЛЕННОЙ КРИСТАЛЛИЗАЦИИ}

А.П. Щербань

${ }^{a}$ Национальный научный центр Харьковский физико-технический институт

ул. Академическая, 1, 61108, Харьков, Украина

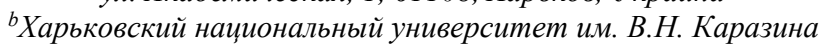

пл. Свободы, 4, Харьков, Украина

Исследован процесс получения высокочистых монокристаллов Сd вертикальной направленной кристаллизацией (ВНК) по методу Бриджмена из расплава. Получены монокристаллы с преимущественным направлением роста [11.2] и [10.3]. Углы отклонения направления роста относительно оси образцов составляют $\alpha=27,2^{\circ}$ и $\alpha=0,5^{\circ}$. Определены кристаллическое совершенство, микроструктура и микротвердость выращенных монокристаллов. Как показывает рентгеноструктурный анализ, в данном варианте ВНК высокочистого кадмия, совершенная монокристаллическая структура не достигается. В начальной части присутствуют отдельные зерна с различной ориентацией, количество которых уменьшается в конечной части монокристалла. Это приводит к формированию более совершенной монокристаллической структуры с преимущественной ориентацией, которая занимает все сечение кристалла. Определена микротвердость верхней и нижней частей монокристаллов. Более загрязненные конечные части кристаллов имеют более низкую микротвердость, чем начальные части. Исследован примесный состав начальной и конечной частей монокристаллов, полученных из кадмия различной чистоты. Эффективность перераспределения примесных элементов вдоль кристаллов одинакова для различных марок кадмия. Разработанный процесс ВНК может быть использован для выращивания монокристаллов легкоплавких металлов, таких как $\mathrm{Zn}, \mathrm{Pb}, \mathrm{Te}, \mathrm{In}, \mathrm{Bi}, \mathrm{Sn}$ и др.

КЛЮЧЕВЫЕ СЛОВА: кадмий, вертикальная направленная кристаллизация, монокристаллы, направление роста, микроструктура, микротвердость, примесный состав 